\title{
Cytology reveals diverse cell morphotypes and cell-in-cell interactions in normal collector sea urchins Tripneustes gratilla
}

\author{
Thierry M. Work ${ }^{1, *}$, Elena Millard ${ }^{1,2}$, Daniela B. Mariani ${ }^{1,3}$, Tina M. Weatherby ${ }^{4}$, \\ Robert A. Rameyer ${ }^{1}$, Julie Dagenais ${ }^{5}$, Renee Breeden ${ }^{1}$, Allison M. Beale ${ }^{6}$ \\ ${ }^{1}$ US Geological Survey, National Wildlife Health Center, Honolulu Field Station, Honolulu, HI 96850, USA \\ ${ }^{2}$ College of Veterinary Medicine, Michigan State University, East Lansing, MI 48824, USA \\ ${ }^{3}$ Federal Rural University of Pernambuco, Department of Veterinary Medicine, Recife, Pernambuco 52171-900, Brazil \\ ${ }^{4}$ University of Hawaii, Pacific Biosciences Research Center, Biological Electron Microscope Facility, Honolulu, HI 96822, USA \\ ${ }^{5}$ IAP World Services (under contract to the US Geological Survey), Cape Canaveral, FL 32920, USA \\ ${ }^{6}$ Leeward Community College, Pearl City, HI 96782, USA
}

\begin{abstract}
Echinoderms such as sea urchins are important in marine ecosystems, particularly as grazers, and unhealthy sea urchins can have important ecological implications. For instance, unexplained mortalities of Diadema antillarum in the Caribbean were followed by algal overgrowth and subsequent collapse of coral reef ecosystems. Unfortunately, few tools exist to evaluate echinoderm health, making management of mortalities or other health issues problematic. Hematology is often used to assess health in many animal groups, including invertebrates, but is seldom applied to echinoderms. We used a standard gravitometric technique to concentrate fixed coelomocytes from the collector sea urchin Tripneustes gratilla onto microscope slides, permitting staining and enumeration. Using Romanowsky stain and electron microscopy to visualize cell details, we found that urchin cells could be partitioned into different morphotypes. Specifically, we enumerated phagocytes, phagocytes with perinuclear cytoplasmic dots, vibratile cells, colorless spherule cells, red spherule cells, and red spherule cells with pink granules. We also saw cell-in-cell interactions characterized by phagocytes apparently phagocytizing mainly the motile cells including red spherule cells, colorless spherule cells, and vibratile cells disproportionate to underlying populations of circulating cells. Cell-in-cell interactions were seen in $71 \%$ of sea urchins, but comprised $<1 \%$ of circulating cells. Finally, about $40 \%$ of sea urchins had circulating phagocytes that were apparently phagocytizing spicules. The coelomic fluid collection and slide preparation methods described here are simple, field portable, and might be a useful complementary tool for assessing health of other marine invertebrates, revealing heretofore unknown physiological phenomena in this animal group.
\end{abstract}

KEY WORDS: Echinoderm · Hematology $\cdot$ Coelomocytes $\cdot$ Light microscopy $\cdot$ Electron microscopy

\section{INTRODUCTION}

Sea urchins are a keystone species in coral reef ecosystems, because their grazing activities are critical to maintaining balance between faster-growing macroalgae and slower-growing corals (Ogden \& Lobel

${ }^{*}$ Corresponding author: thierry_work@usgs.gov
1978). This interdependency was illustrated during the mass die-off of the dominant sea urchin, Diadema antillarum, in the Caribbean in the early 1980s. The die-off wiped out $>90 \%$ of sea urchins from the entire region within $1 \mathrm{yr}$ (Lessios 1988), and populations have yet to recover (Lessios 2016). The sea urchin restricted. Authors and original publication must be credited. 
mortality was followed by a mass mortality of dominant Acropora corals leading to a widespread restructuring of the reef ecosystem from highly 3-dimensional arborescent to low encrusting corals, resulting in a marked reduction in diversity of biota (Aronson \& Precht 2001). The cause of the Diadema mortality, thought to be infectious, was never determined.

Loss of grazing fish and sea urchins in Hawaii has resulted in the establishment of invasive algae, a particular problem in Kaneohe Bay, Oahu (Stimson et al. 2001). Since 2014, the State of Hawaii has tried to control invasive marine macroalgae in Kaneohe Bay using a mechanical suction device to aspirate algae from corals (Westbrook et al. 2015). To complement these efforts, the state has also undertaken a rearing program to raise and release as well as translocate collector sea urchins Tripneustes gratilla into the bay (Westbrook et al. 2015). Collector sea urchins were historically present in Kaneohe Bay (Ogden et al. 1989) but have since disappeared for unknown reasons. Reintroduction of sea urchins was done in recognition that this dominant species is an important grazer in Hawaiian coral reef ecosystems (Stimson et al. 2007), with the hope that sea urchins would contribute to long-term control of invasive algae; success of this effort is still being evaluated. Given the importance of T. gratilla to coral reefs, and because translocation and hatchery-release activities can have important health ramifications in terms of disease transfer, we developed a tool to assess antemortem health in this species.

Hematology is commonly used to assess health of various animals (Schalm 1962). For sea urchins, hematological exams are usually limited to examining live cells in hanging drops or hemocytometers (Johnson 1969b, Silva 2013). Using these methods, 4 types of coelomocytes are recognized in sea urchins: phagocytes, red spherule cells, colorless spherule cells, and vibratile cells (Chia \& Xing 1996, Silva 2013, Smith et al. 2018). Three additional morphological types of phagocytes (discoidal, polygonal, and small phagocytes) have also been described on wet mounts (Smith et al. 2006); however, morphology of a given live cell can vary with time (Liebman 1950, Boolootian \& Giese 1958). The phagocytes are the most numerous morphotype and appear to be the first line of host defense by means of phagocytosis. The role of colorless spherule cells and vibratile cells is less clear, but red spherule cells have been shown to be elevated in inflammatory response (Chia \& Xing 1996, Silva 2013) or environmental stress (Pinsino et al. 2008). In contrast to examination of live cells, reports of stained cytologic preparations of sea urchin coelomocytes are rare; we could only find 3 reports: Johnson (1969a) used a battery of cytochemical stains including Giemsa to describe coelomocyte morphology in Strongylocentrotus sp.; Queiroz \& Custodio (2015) examined cytologic preparations from Eucidaris tribuloides using toluidine blue, trichrome, or hematoxylin and eosin; and Liebman (1950) described cells from Arbacia punctulata using Wright's stains.

While wet mounts of cells allow enumeration of cells ml ${ }^{-1}$ of coelomic fluid and observation of live cell behavior, examination of Romanowsky-stained slide preparations, a routine part of hematologic exams in other animals, is simple to do and permits a more detailed enumeration of morphologies not readily recognizable in wet mounts of live cells (Schalm 1962). Here, using standard hematology techniques, we identified a variety of morphotypes of coelomocytes in T. gratilla. We also show that cell-in-cell interactions (apparent phagocytosis of sea urchin coelomocytes by sea urchin phagocytes), a heretofore undocumented phenomenon in sea urchins, is common in healthy $T$. gratilla and is targeted to particular cell morphotypes.

\section{MATERIALS AND METHODS}

\subsection{Sample collection, preparation, and light microscopy}

In 2016, 20-40 collector sea urchins were sampled each month from 2 sites on South Oahu using SCUBA; these sites were not part of the areas where sea urchins are being released. Sea urchins were held (<30 min) in seawater in 201 buckets whilst awaiting coelomic fluid sampling and were released back into the ocean immediately thereafter. Sea urchins were weighed to the nearest $1 \mathrm{~g}$, and test diameter was measured to the nearest $1 \mathrm{~mm}$ at the widest point using plastic calipers. Because echinoderm coelomocytes have a propensity to clot or deform rapidly when withdrawn from the coelomic cavity (Liebman 1950, Boolootian 1962), we withdrew $0.05 \mathrm{ml}$ of coelomic fluid directly into $0.05 \mathrm{ml}$ of fixative. The fixative was prepared by mixing $10 \%$ formalin with artificial seawater (ASW; Instant Ocean) made according to the manufacturer's instructions. Fixative was preloaded into $1 \mathrm{cc}$ syringes with a 22-gauge, $2.57 \mathrm{~cm}$ needle, and coeolomic fluid was drawn by inserting the needle ca. 2-5 $\mathrm{mm}$ into the peristomial membrane. In this way, the cells were fixed and killed immediately, ensuring minimal morphologic distortions that often occur in coelomocytes once outside the host (Liebman 1950, Boolootian \& Giese 1958). 
To make the slides, we used a modified gravitational sedimentation system (Moore 2017) comprising a microscope slide, 2 barrels cut from 1 cc syringes, small binder clips, and No. 2 Whatman filter paper cut to fit the microscope slide (Fig. 1). Two holes were punched in the paper over which we centered and affixed the 2 syringe barrels using binder clips. Fixed coelomic fluid $(0.05 \mathrm{ml})$ was dispensed directly onto the slide in each barrel, and the filter paper wicked away fluid, thereby concentrating coelomocytes into a small enough area to allow enumeration without cells piling upon themselves. Once dried, the slides were stained with Romanowsky (Romanowsky 1891) stain (Protocol Hema 3, Thermo Fisher Scientific) using standard techniques. We found from preliminary empirical trials that this slide preparation/staining method gave superior cell morphology and density rather than the classic push smear or cover slip method (Perpiñan et al. 2006) that proved too damaging to cells and resulted in unrealistically low cell densities to permit efficient cell counting (Liebman 1950). Moreover, the presence of 2 spots of cells allowed the
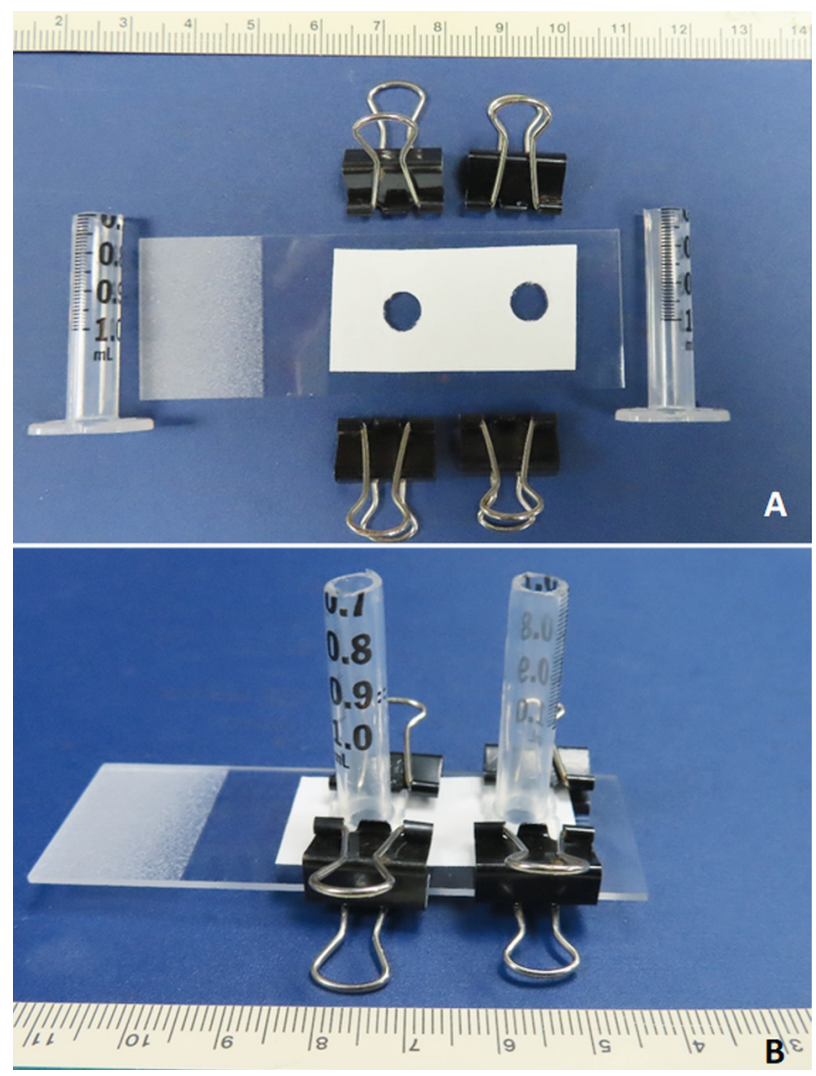

Fig. 1. Gravitational sedimentation system used to make coelomic fluid slides for Tripneustes gratilla. Microscope slide, filter paper with holes, clips, and 1 cc syringe barrels cut to size (A) prior to and (B) after assembly. Ruler is in $\mathrm{cm}$ user to choose which gave the best distribution and density for enumeration.

For differential counts, 400 coelomocytes stained with Romanowsky were counted for each sea urchin and enumerated to phagocytes, phagocytes with cytoplasmic perinuclear dot, vibratile cells, colorless spherule cells, red spherule cells, red spherule cells with pink granules, and apparently phagocytized spicules. Phagocytes apparently phagocytizing other cells (cell-in-cell interactions) were enumerated separately. In cases of cell-in-cell interactions, the cell type being apparently phagocytized was also enumerated. Counts of different cell morphologies were converted to percentages. To assess possible seasonal trends, we plotted size distribution of sea urchins and percent cell morphotypes by month.

\subsection{Percoll gradients and separation of cells}

To relate morphology of coelomocytes seen on Romanowsky stain to that seen in live cells, we used Percoll density centrifugation to segregate cells into smaller groups. Live coelomocytes were sampled from Tripneustes gratilla by withdrawing $4 \mathrm{ml}$ of coelomic fluid directly into $4 \mathrm{ml}$ of ice-cold $\left(4^{\circ} \mathrm{C}\right)$ anticoagulant buffer (ACB) formulated exactly as described by Gross et al. (2000). Percoll was made isotonic with ASW by blending 9 parts of Percoll to 1 part of $10 \times$ ASW. Isotonic Percoll was then layered in a $15 \mathrm{ml}$ conical tube in $2 \mathrm{ml}$ layers comprising $90 \%$ Percoll overlaid by 75,65 , and $45 \%$ layers for a total of $8 \mathrm{ml}$. Four ml of coelomic fluid in ice-cold ACB was then carefully overlaid on the Percoll gradient, tubes were centrifuged at $1500 \times g\left(30 \mathrm{~min}\right.$ at $\left.4^{\circ} \mathrm{C}\right)$ in a swing rotor centrifuge, each layer subsequently harvested, and rinsed twice in $10 \mathrm{ml}$ of cold ASW. Fractions were observed as wet mounts, used to make Romanowsky-stained slides as above, or used for electron microscopy (Section 2.3). Because Romanowsky staining sometimes degranulated red spherule cells, these were confirmed morphologically by locating the fully granulated cells on unstained slides with a Lovins Micro-Slide Field Finder and relocating the same cells after staining.

\subsection{Electron microscopy}

For electron microscopy, $1 \mathrm{ml}$ of coelomic fluid was withdrawn into $1 \mathrm{ml}$ of modified Karnovsky's fixative (Karnovsky 1965) comprising $2 \%$ paraformaldehyde and $2.5 \%$ glutaraldehyde in ASW; the cells were 
Table 1. Mean, SD, and range of percentages of each cell type in 340 Tripneustes gratilla sampled in 2016 along with percentage of 1114 cell types undergoing cell-in-cell interactions by phagocytes, and percentage of urchins observed with a given cell type. na: not applicable; we did not distinguish between phagocytes and phagocytes with a perinuclear cytoplasmic dot for phagocytized cells

\begin{tabular}{|c|c|c|c|c|c|}
\hline Cell morphotype & Mean & $\mathrm{SD}$ & Range & $\begin{array}{l}\text { \% Cell-in-cell } \\
\text { interactions }\end{array}$ & $\%$ Urchins \\
\hline Phagocyte & 73.7 & 11.4 & $16.3-98.5$ & 2.7 & 100 \\
\hline Phagocytes with perinuclear cytoplasmic dot & 8.3 & 8.7 & $0-43$ & na & 100 \\
\hline Colorless spherule cell & 5.2 & 3.5 & $0-32$ & 21.8 & 99 \\
\hline Red spherule cell with pink granules & 0.7 & 1.4 & $0-12$ & 13.2 & 54 \\
\hline Red spherule cell & 3.8 & 4.2 & $0-38.8$ & 55 & 98 \\
\hline Vibratile cell & 7.3 & 4.5 & $0-27$ & 7 & 99 \\
\hline Phagocyte with cell-in-cell interactions & 0.8 & 1.1 & $0-6.8$ & na & 71 \\
\hline Phagocytized spicule & 0.3 & 1.4 & $0-25$ & na & 34 \\
\hline
\end{tabular}

then centrifuged at $1000 \times g$ for 1 min, fluid was decanted, and cells were overlaid with fixative. These cells and Percoll layers (Section 2.2) were processed as described by Work et al. (2017). Briefly, cells were rinsed in sodium cacodylate buffer with $0.45 \mathrm{M}$ sucrose, post fixed with $1 \%$ osmium tetroxide, dehydrated in ethanol and propylene oxide, embedded in resin, sectioned, stained with uranyl acetate/lead citrate, and viewed on a Hitachi HT7700 transmission electron microscope (TEM) at $100 \mathrm{kV}$. Identity of cells was confirmed by repeating this process using cells fractionated from Percoll layers (Section 2.2) fixed for electron microscopy as phagocytes, vibratile cells, colorless spherule cells, and mixed red spherule cells and red spherule cells with pink granules.

\subsection{Statistics}

Test diameter and percent cell counts between months were compared with non-parametric KruskalWallis ANOVA (Kruskal \& Wallis 1952), because data did not fit assumptions of normality as determined by the Shapiro-Wilk test (Shapiro \& Wilk 1965). Because these 9 comparisons were not independent, we did a Bonferroni adjustment of the significant $p$-value (0.05/9 or 0.005) to account for the number of statistical comparisons (Rice 1989). Tukey pairwise post hoc comparisons were made in cases where differences were significant. All analyses were done with $\mathrm{R}$ version 3.5.3 (R Development Core Team 2011).

\section{RESULTS}

We sampled 340 sea urchins from JanuaryDecember 2016. The mean \pm SD (range) test dia- meter and weight were $73 \pm 11 \mathrm{~mm}(31-103 \mathrm{~mm})$ and $155 \pm 67 \mathrm{~g}$ (18-388 g). Test diameter and percent differential counts did not differ significantly between months.

Phagocytes were the most common cell type, comprising a mean of $73 \%$ of cells and characterized by a homogeneous amorphous pale blue cytoplasm (Table 1). Live phagocytes ranged from petalloid to fillipodial to amoeboid depending on time (5-60 min) under observation. On Romanowsky, phagocytes with cytoplasmic perinuclear dot comprised about $8 \%$ of the cell population and were distinguished from regular phagocytes by the presence of a distinct deeply basophilic perinuclear cytoplasmic dot in the cytoplasm (Fig. 2A,B). Colorless spherule cells comprised about $5 \%$ of cells. Live cells were round to oblong with densely packed, variably sized intracytoplasmic granules (Fig. 2C) and moved slowly by extending cytoplasm that then filled with granules (see Video S1 at www.int-res.com/articles/suppl/ d142p063_supp/). On Romanowsky, intracytoplasmic granules of colorless spherule cells stained deep blue (Fig. 2D). Rapidly erratic and non-directional motile live vibratile cells with characteristic flagella (Fig. 2E) comprised about $7 \%$ of cells. On Romanowsky, these cells had a pink cytoplasm with small arrayed granules and a flagellum often detached (Fig. 2F). Live red spherule cells were oblong, had red granules (Fig. 2G), a similar motility as colorless spherule cells (Video S2), and comprised about $4 \%$ of cells. When fixed and stained, red spherule cells typically degranulated and were packed with clear vacuoles (Fig. 2H). The degranulation phenomenon during fixation/staining in red spherule cells was confirmed by locating specific cells with a Lovins Micro-Slide Field Finder prior to and after staining when red granules were and were not visible, respectively. Red 
spherule cells with pink granules comprised $<1 \%$ of cells, and on wet mounts were similar to but smaller than colorless spherule cells with small granules. On Romanowsky, pink granule cells had densely packed pink intracytoplasmic granules (Fig. 2I). Apparently phagocytized spicules comprised $<1 \%$ of cells and were notable by the presence of variably sized small to large bihamate crystalline structure spanned by a delicate mesh of cytoplasm with an eccentric nucleus (Fig. 2J-L). More than $98 \%$ of sea urchins sampled had phagocytes, red and colorless spherule cells, and vibratile cells, over half had red spherule cells with pink granule cells, and a third had apparently phagocytized spicules (Table 1).

Percoll layers isolated 4 populations of cells. The top layer (45\% Percoll) had phagocytes and phagocytes with intracytoplasmic perinuclear dots; the second layer (65\% Percoll) had colorless spherule cells; the third layer (75\%) had vibratile cells; and red spherule cells and red spherule cells with pink granules went to the bottom of the tube. Apparently phagocytized spicules were not seen on Percoll assays. This segregation of cell populations with Percoll allowed us to identify particular cell types on electron microscopy and relate them back to light micrographs. On ultrastructure, phagocytes had numerous intracytoplasmic vacuoles (Fig. 3A) whilst phagocytes with a perinuclear cytoplasmic dot had a variably sized reticulated to electrondense punctate structure near the nucleus (Fig. 3B). Colorless spherule cells (Fig. 3C) were closely packed with membrane-bound granules with electron-lucent cores. Red spherule cells had numerous electron-lucent granules with electron-dense cores (Fig. 3D). Vibratile cells were distinguished by presence of a single flagellum with numerous intracytoplasmic granules, some of which had an electron-dense core (Fig. 3E). Due to their scarcity, we were unable to obtain TEM images of apparently phagocytized spicules or red spherule cells with pink granules.

Cell-in-cell interactions by phagocytes were seen on average in $<1 \%$ of cells (Table 1 ). Of 1114 phagocytes apparently phagocytizing cells, red spherule cells (Fig. 3F,G) dominated (55\%) followed by colorless spherule cells (Fig. 3H,I), red spherule cells with pink granules (Fig. 3J), and vibratiles (Fig. 3K). Apparent phagocytosis of spicules and phagocytes (Fig. 3L) was rare (Table 1). Cell-in-cell interactions of a particular cell type appeared independent of the numbers of cells in coelomic fluid (Appendix, Fig. A1). Of 340 sea urchins, 242 (71\%) had cell-incell interactions (Table 1).

\section{DISCUSSION}

The use of a gravitational sedimentation system in combination with immediate fixation of coelomocytes permits preparations of cells suitable for examination on cytology and is a low-cost, simple technique to do hematology exams for Tripneustes gratilla that is likely applicable to most echinoderms. This method offers several advantages over examination of live cells on phase contrast (Johnson 1969b), including (1) storing of samples for later examination, making this technique amenable for remote field situations; (2) increased details of cell morphology as the result of Romanowsky staining; and (3) visualization of phenomena (cell-in-cell interactions) previously undocumented in echinoderms. As such, this method could complement existing techniques that depend on examination of live cells to provide data on numbers of coelomocytes $\mathrm{ml}^{-1}$ of coelomic fluid, examine changes in cell morphology over time, and evaluate hematological responses of sea urchins to various environmental changes (Matranga et al. 2005, Pinsino et al. 2008)

The percentages of vibratile cells, red and colorless spherule cells, and phagocytes (Chien et al. 1970) in T. gratilla are within the ranges of those documented for other species of echinoderms. For instance, in his review of echinoderm immunology, Silva (2013) found the following ranges: phagocytic phagocytes, 60-70\%; vibratile cells, 15-20\%; red spherule cells, 5-10\%; and colorless spherule cells, 5-10\%. In comparison, we found mean percentages of 73, 7, 4, and $5 \%$ for phagocytes, vibratile, red, and colorless spherule cells, respectively; these ranges certainly fit within parameters outlined in the literature (Table 1). Moreover, Romanowsky-stained slides revealed 2 additional morphologies, i.e. phagocytes with a cytoplasmic perinuclear dot and red spherule cells with pink granules. The nature of the perinuclear cytoplasmic dot in type 1 phagocytes could not be determined from electron microscopy; however, we saw no evidence on TEM that they were infectious organisms like bacteria or virus inclusions (Cheville 1976), so further research is needed to determine their origin. Red spherule cells with pink granules sedimented at the same layer as red spherule cells on Percoll sedimentation and on live preparation look like smaller versions of colorless spherule cells with smaller granules. However, unlike the red spherule cells, red spherule cells with pink granules did not degranulate with fixation, suggesting a different composition of their intracytoplasmic granules. Apparently phagocytized spicules with their biha- 


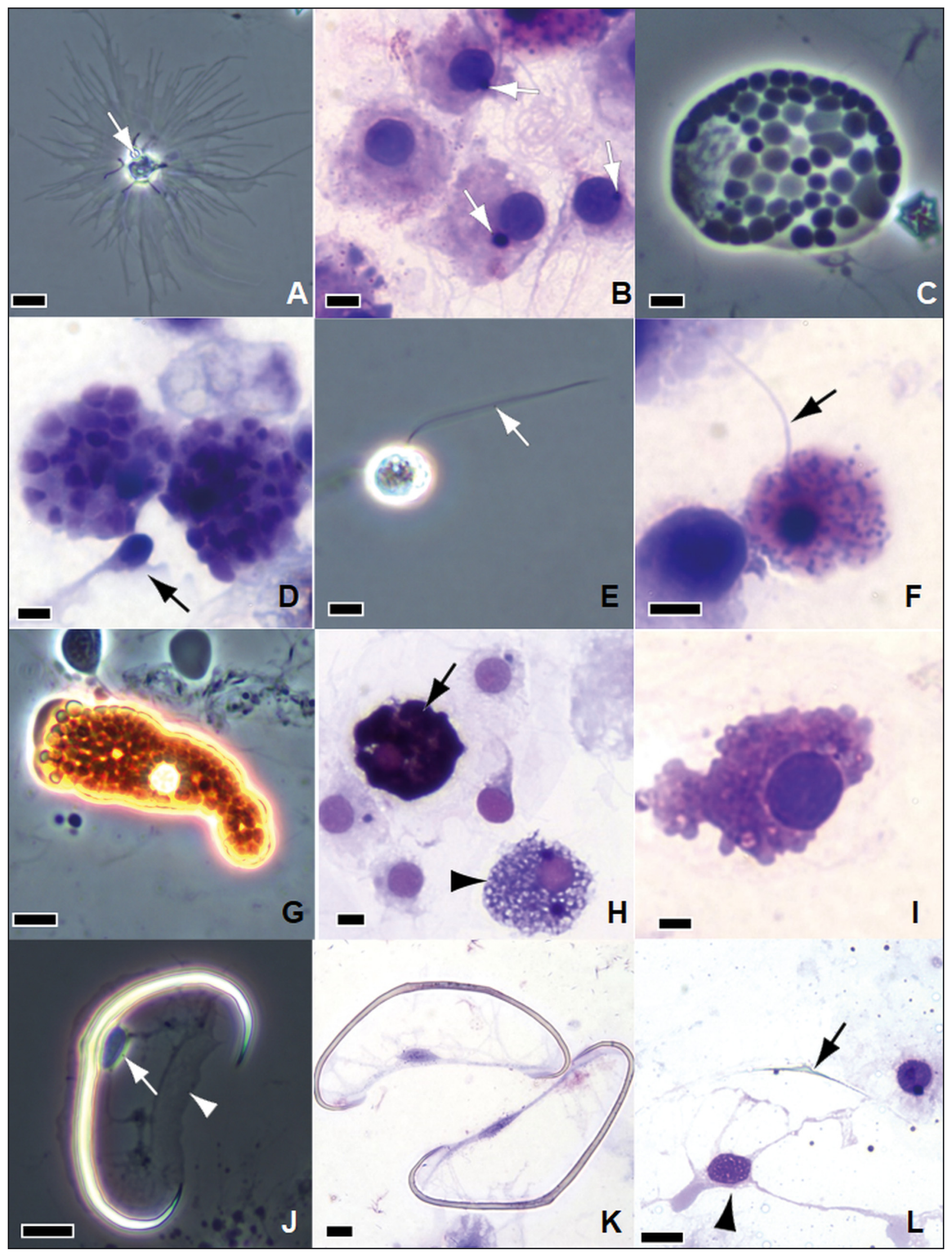


mate crystalline structure are reminiscent of spicules seen in tissues of gonads and tube feet of Echinometra sp. (Kelso 1970, Rahman et al. 2001). However, the presence of bihamate spicules among circulating coelomocytes has rarely been documented in echinoderms, the only instance being in Echinometra sp. from the Pacific where they were transiently abundant in circulation (Boolootian 1962). We cannot confirm whether the cell structures (nuclei and diaphanous membrane spanning the spicule) were phagocytes attempting to phagocytize wayward spicules that were sloughed from tissues or actual cells engaged in spicule morphogenesis. The presence of incomplete bihamate spicules associated with these cells (Fig. 2L) suggests to us the latter as a possibility; moreover, in sea urchins, spicules originate from cells (Horstadius 1939), so this is a reasonable conjecture. The scarcity of this cell type makes sorting out their origin a challenge, but perhaps one avenue might be to look at other echinoderm species, such as Echinometra sp., where apparently phagocytized spicules are reportedly more numerous (Boolootian 1962). Given that red spherule cells with pink granules and apparently phagocytized spicules comprise $<1 \%$ of the cell population and were found in 54 and $34 \%$ of sampled sea urchins, respectively, it is not surprising that they have not been documented previously. Determining whether similar proportions of these cell types are found in other sea urchins might be a fruitful avenue of research.

The ultrastructure of the 4 major Tripneustes coelomocytes is similar to those for Strongylocentrotus sp. (Chien et al. 1970, Vethamany \& Fung 1972). We suspect that Vethamany \& Fung (1972) might have misidentified colorless and red spherule cells because colorless spherule cells in their study looked more like red spherule cells in Tripneustes (this study) and Strongylocentrotus (Chien et al. 1970). Possibly these cell types were mis-identified on ultrastructure for
Strongylocentrotus, because in that study (Vethamany \& Fung 1972), cells were not segregated using sediment gradients prior to TEM.

The phenomenon of cell-in-cell interactions seen in $71 \%$ of sea urchins sampled here indicates that this phenomenon must have some biological importance. That phagocytes are enveloping target cells is evident because of the presence of continuous plasma membrane of phagocytes around apparently phagocytized cells as seen on electron microscopy (Fig. 3FL). Interestingly, the cells within the phagocytes appeared intact with no evident visible pathology, and although it might be tempting to conclude that phagocytes were phagocytizing cells, we cannot state this definitely. Cell-in-cell interactions vary depending on the mechanisms involved (Brown et al. 2015, Fais \& Overholtzer 2018). In classical phagocytosis of cells, phagocytized cells are usually apoptotic (Chao et al. 2011); however, on light and electron microscopy, we saw none of the morphologic hallmarks of apoptosis, such as membrane blebbing, karyorrhexis, or apoptotic bodies (Elmore 2007), nor did we see evidence of necrosis such as karyorrhectic nuclei (Cheville 1976) in cells that were apparently phagocytized by phagocytes.

Phagoptosis is a process in mammals, worms, and flies whereby phagocytes ingest intact cells based on presentation of specific membrane markers that signal to phagocytes whether or not the target cells should be ingested (Brown \& Neher 2012). Phagoptosis leads to death of the ingested cell; however, we could not determine the fate of ingested cells in this study nor did we document the presence of plasma markers that serve as signals for phagocytes to phagocytize cells.

Entosis occurs when one cell actively invades the cytoplasm of another cell, leading to death of the invading cell (Overholtzer et al. 2007), and is found most often in cancers. The physics of entosis stipulate

Fig. 2. (A, $, E, G, J)$ Live and $(B, D, F, H, I, K, L)$ fixed and Romanowsky-stained coelomocytes from Tripneustes gratilla. (A) Phagocyte with perinuclear cytoplasmic dot characterized by single intracytoplasmic structure (arrow) and fillopodial cytoplasm. (B) Phagocytes with perinuclear intracytoplasmic dot (arrows); note pale blue/purple cytoplasm with delicate strands surrounding round distinct nuclei. (C) Colorless spherule cell; note variably sized intracytoplasmic granules with nucleus to the left. (D) Colorless spherule cells with small phagocyte (arrow); note densely packed blue granules obscuring nucleus. (E) Vibratile cell; note flagellum (arrow). (F) Vibratile cell; note light pink cytoplasm with arrays of delicate granules and flagellum (arrow). (G) Red spherule cell with distinct red intracytoplasmic granules, nucleus (center), and locomotory pseudopod (left). (H) Partially degranulated (arrowhead) and fully granulated (arrow) red spherule cells among phagocytes and phagocytes type 1; note dense black pigmentation of fully granulated red spherule. (I) Red spherule cell with pink granules; note distinct round nucleus surrounded with coarse pink granules. (J) Live, apparently phagocytized spicule; note nucleus (arrow) and diaphanous cell membrane (arrowhead) encompassing bihamate crystal. (K) Large apparently phagocytized spicules; note nuclei and membranes as in J enclosing bihamate crystals. (L) Putative early- or late-stage spicule with presumed phagocyte cell nucleus (arrowhead) surrounded by cytoplasm with long pseudopodia adjoining incomplete bihamate crystal (arrow). Scale bars $=$ $(\mathrm{A}, \mathrm{K}, \mathrm{L}) 10 \mu \mathrm{m},(\mathrm{B}-\mathrm{J}) 5 \mu \mathrm{m}$ 

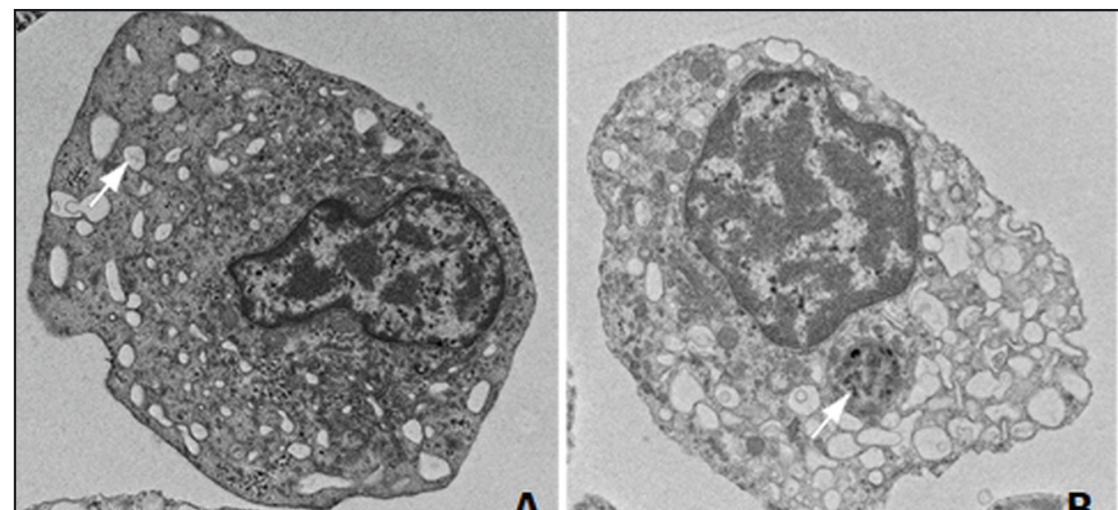

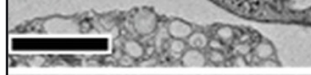

A
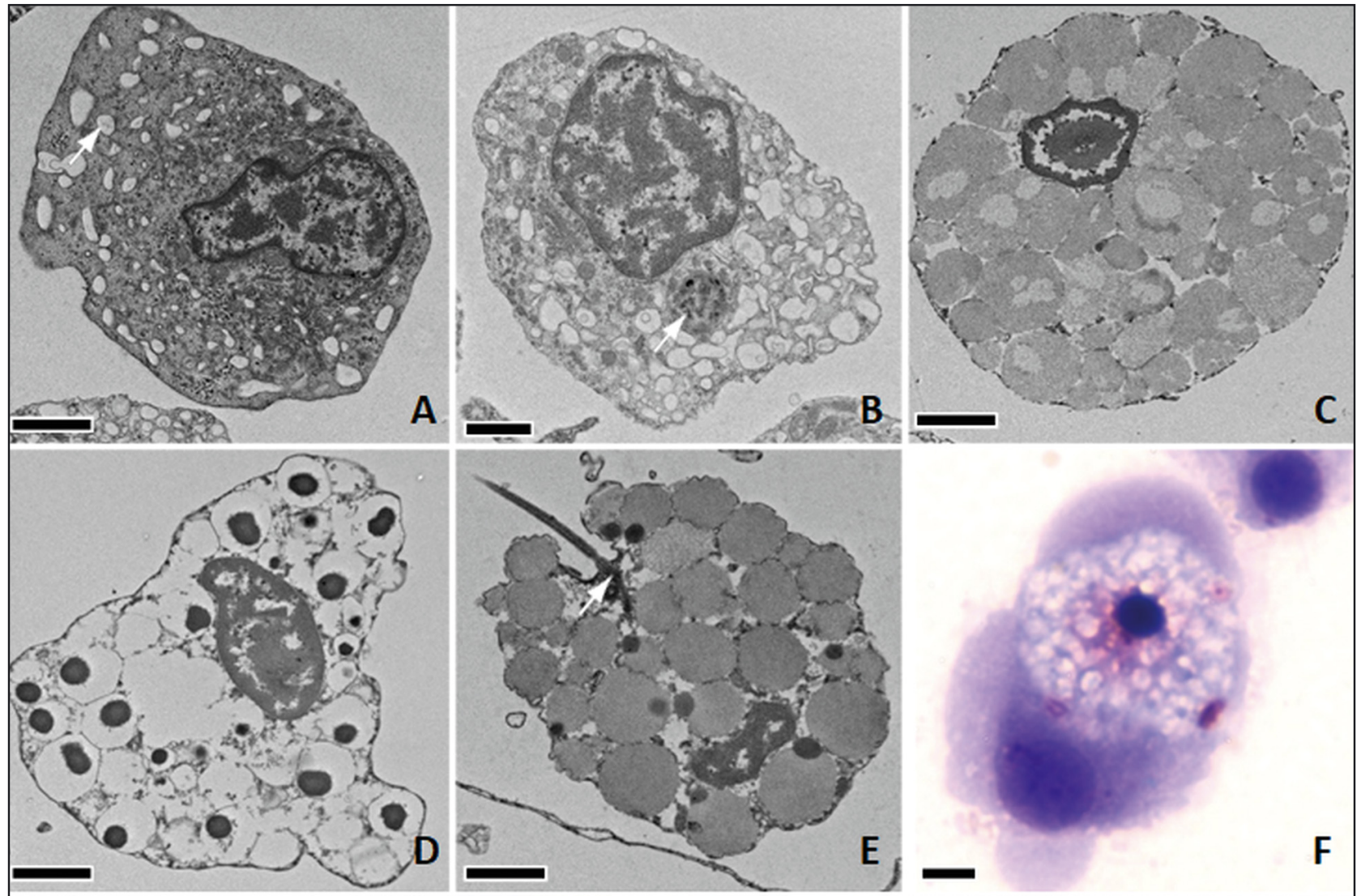

F
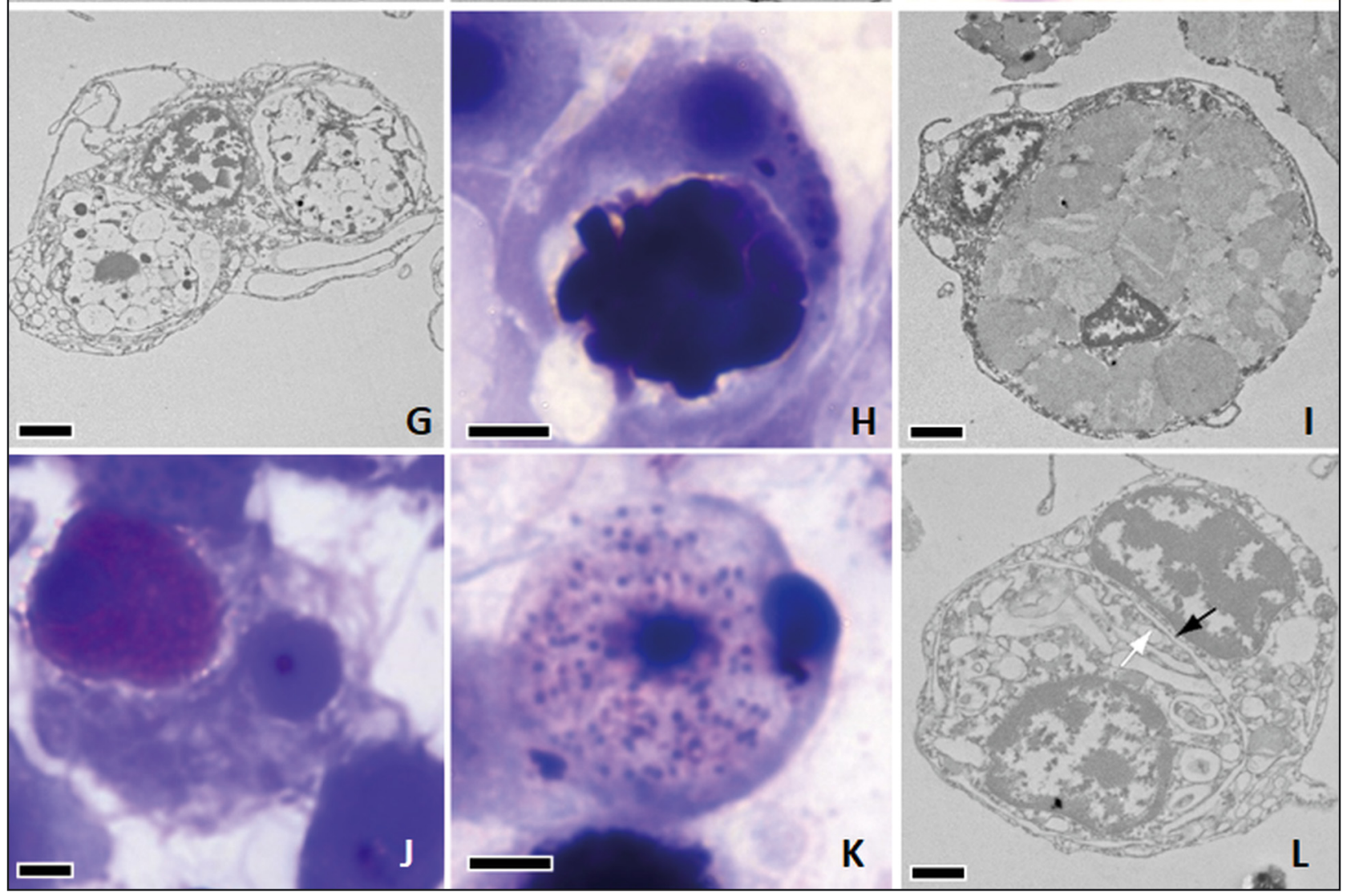
that the invading cell has stiffer cytoskeletal structures than the one being invaded (Ning et al. 2015), and entosis involves specific membrane markers and presence of adherens junctions between the cell membranes, something not seen on TEM here.

Emperipolesis (Humble et al. 1956) is a more general term describing cell-in-cell interactions involving different cell types that usually lead to death of invading or invaded cells (Xia et al. 2008). In the case of T. gratilla, given that we do not know the fate of either the phagocytes or the cells within them, we have opted to be more conservative and term what we saw here a cell-in-cell interaction. Sorting out the precise mechanisms of cell-in-cell interactions in $T$. gratilla will likely require development of membrane markers and documenting the fate of the interacting cells, which may be challenging given that cell-incell interactions comprise $<1 \%$ of cell populations.

Phagocytosis in echinoderms is well documented (Bertheussen \& Seljelid 1978, Bertheussen 1981a,b); however, most such studies have looked at phagocytosis of materials such as latex beads, bacteria, or India ink iatrogenically introduced into sea urchins. We know of only one instance of cell-in-cell interactions of red spherule cells in coelomocytes of Strongylocentrotus after $7 \mathrm{~h}$ of observation in vitro (Chien et al. 1970). Whilst the cell-in-cell interactions seen here might be an artefact of processing or could have occurred after placement on slides, we think this unlikely because cells were fixed immediately in formalin upon withdrawal from the sea urchin. Indeed, fixing coelomocytes in sea urchins was used over $70 \mathrm{yr}$ ago to ensure consistent cell morphology for microscopic examination (Liebman 1950).

We are unaware of other documentations of cell-incell interactions in the coelomic fluid of live, apparently healthy echinoderms. Interestingly, the prevalence of cell-in-cell interactions did not reflect the underlying relative numbers of circulating cells (Table 1). For instance, red spherule cells comprised ca. $4 \%$ of circulating coelomocytes but $55 \%$ of apparently phagocytized cells. Possibly, red spherule cells are preferentially targeted because of their propensity to degranulate and release echinochrome, a potent iron-scavenging compound, into the coelomic fluid (Coates et al. 2018), which in large amounts might be detrimental to the host. Colorless spherule and red spherule cells with pink granules were also preferentially targeted by cell-in-cell interactions; however, given the uncertain function of these cells, this is difficult to explain. In contrast to the aforementioned cells, cell-in-cell interactions with phagocytes was relatively rare (comprising $<3 \%$ of instances; Table 1) despite the fact that this is the most abundant cell. Perhaps cell-in-cell interactions in sea urchins play a housekeeping role, removing cells from circulation that could be potentially damaging to the host or that have outlived their usefulness. For instance, phagocytosis of neutrophils and red cells in mammals serves to remove senescent cells (Brown et al. 2015), and perhaps a similar mechanism occurs in sea urchins. It seems noteworthy that cell-in-cell interactions predominantly target the motile cells of T. gratilla, perhaps lending some credence to the hypothesis that phagocytes might be actively invaded by motile cells. Cell-in-cell interactions seem to merit further investigation to see if it this phenomenon is widespread in other echinoderms, why exactly certain cell types are targeted over others, and determine its role in regulating numbers of coelomocytes in sea urchins.

Seasonal variation in cell counts in echinoderms has not been investigated; however, it is known that at least for cell function, seasonal variation in physiological function of marine invertebrates does exist. For instance, in shore crabs Carcinus maenas in England, phagocyte activity was higher in winter and spring, whereas coelomic fluid oxidant status was lower in winter (Dissanayake et al. 2011). Here we showed that within limits of the variation in counts, there was no evident seasonality in differential cell counts for T. gratilla in Hawaii. Shifts in percentages of coelomocytes on hematology exams of T. gratilla could be used as an indicator of health. For example,

Fig. 3. (A-E, G,I,L) Electron and $(\mathrm{F}, \mathrm{H}, \mathrm{J}, \mathrm{K})$ light micrographs of coelomocytes and cell-in-cell interactions in Tripneustes gratilla. (A) Phagocyte with numerous intracytoplasmic vacuoles (arrow). (B) Phagocyte with perinuclear cytoplasmic dot (arrow). (C) Colorless spherule cell replete with granules with electron-lucent cores. (D) Red spherule cell with electron-lucent granules with central electron-dense core. (E) Vibratile cell replete with granules having moderately electron-dense granules, some with eccentric electron-dense cores and a flagellum (arrow). (F) Phagocytized red spherule cell; note cytoplasm of phagocyte surrounding the cell. (G) Ultrastructure of phagocyte phagocytizing 2 red spherule cells. (H) Phagocytized colorless spherule cell; note cytoplasm of phagocyte enveloping the cell. (I) Ultrastructure of H. (J) Phagocytized red spherule cell with pink granules. (K) Phagocytized vibratile cell. (L) Ultrastructure of phagocytized phagocyte; note plasma membrane of enveloping phagocyte (black arrow) separated from plasma membrane of phagocytized phagocyte (white arrow). Scale bars $=(A, C-E, G, I)$ $2 \mu \mathrm{m},(\mathrm{B}, \mathrm{L}) 0.5 \mu \mathrm{m},(\mathrm{F}, \mathrm{H}, \mathrm{J}, \mathrm{K}) 5 \mu \mathrm{m}$ 
Pinsino et al. (2008) and Pinsino \& Matranga (2015) used a combination of heat shock proteins and coelomocyte counts to evaluate responses of sea urchins to environmental changes, and perhaps the methods outlined here might be used to complement such approaches to assess echinoderm health.

Acknowledgements. Susan Knowles and 3 anonymous reviewers provided constructive comments on earlier versions of this manuscript. Any use of trade, firm, or product names is for descriptive purposes only and does not imply endorsement by the US Government. Data collected for this study are available at https://doi.org/10.5066/P9VUQH51.

\section{LITERATURE CITED}

Aronson RB, Precht WF (2001) White-band disease and the changing face of Caribbean coral reefs. Hydrobiologia 460:25-38

Bertheussen K (1981a) Endocytosis by echinoid phagocytes in vitro I. Recognition of foreign matter. Dev Comp Immunol 5:241-250

Bertheussen K (1981b) Endocytosis by echinoid phagocytes in vitro. II. Mechanisms of endocytosis. Dev Comp Immunol 5:557-564

Bertheussen K, Seljelid R (1978) Echinoid phagocytes in vitro. Exp Cell Res 111:401-412

Boolootian RA (1962) The perivisceral elements of echinoderm body fluids. Am Zool 2:275-284

Boolootian R, Giese A (1958) Coelomic corpuscles of the echinoderms. Biol Bull (Woods Hole) 115:53-63

Brown GC, Neher JJ (2012) Eaten alive! Cell death by primary phagocytosis: 'phagoptosis'. Trends Biochem Sci 37:325-332

Brown GC, Vilalta A, Fricker M (2015) Phagoptosis -cell death by phagocytosis- plays central roles in physiology, host defense and pathology. Curr Mol Med 15:842-851

* Chao MP, Majeti R, Weissman IL (2011) Programmed cell removal: a new obstacle in the road to developing cancer. Nat Rev Cancer 12:58-67

Cheville NF (1976) Cell pathology. Iowa State University Press, Ames, IA

Chia F, Xing J (1996) Echinoderm coelomocytes. Zool Stud 35:231-254

Chien PK, Johnson PT, Holland ND, Chapman FA (1970) The coelomic elements of sea urchins (Strongylocentrotus) IV. ultrastructure of the coelomocytes. Protoplasma 71:419-442

Coates CJ, McCulloch C, Betts J, Whalley T (2018) Echinochrome A release by red spherule cells is an iron-withholding strategy of sea urchin innate immunity. J Innate Immun 10:119-130

Dissanayake A, Galloway TS, Jones MB (2011) Seasonal differences in the physiology of Carcinus maenas (Crustacea: Decapoda) from estuaries with varying levels of anthropogenic contamination. Estuar Coast Shelf Sci 93: 320-327

Elmore S (2007) Apoptosis: a review of programmed cell death. Toxicol Pathol 35:495-516

Fais S, Overholtzer M (2018) Cell-in-cell phenomena in cancer. Nat Rev Cancer 18:758-766

Gross PS, Clow LA, Smith LC (2000) SpC3, the complement homologue from the purple sea urchin, Strongylocentrotus purpuratus, is expressed in two subpopulations of the phagocytic coelomocytes. Immunogenetics 51:1034-1044

Horstadius S (1939) The mechanics of sea urchin development, studied by operative methods. Biol Rev Camb Philos Soc 14:132-179

* Humble JG, Jayne WH, Pulvertaft RJ (1956) Biological interaction between lymphocytes and other cells. Br J Haematol 2:283-294

Johnson PT (1969a) The coelomic elements of sea urchins (Strongylocentrotus) II. Cytochemistry of the coelomocytes. Histochemie 17:213-231

Johnson PT (1969b) The coelomic elements of sea urchins (Strongylocentrotus) I. The normal coelomocytes; their morphology and dynamics in hanging drops. J Invertebr Pathol 13:25-41

Karnovsky MJ (1965) A formaldehyde-glutaraldehyde fixative of high osmolality for use in electron microscopy. J Cell Biol 27:137-138

Kelso DP (1970) A comparative morphological and ecological study of two species of the sea urchin genus Echinometra in Hawaii. PhD dissertation, University of Hawaii, Honolulu, HI

Kruskal WH, Wallis WA (1952) Use of ranks in one-criterion variance analysis. J Am Stat Assoc 47:583-621

Lessios HA (1988) Mass mortality of Diadema antillarum in the Caribbean: What have we learned? Annu Rev Ecol Syst 19:371-393

Lessios HA (2016) The great Diadema antillarum die-off: 30 years later. Annu Rev Mar Sci 8:267-283

Liebman E (1950) The leukocytes of Arbacia punctulata. Biol Bull (Woods Hole) 98:46-59

Matranga V, Pinsino A, Celi M, Natoli A, Bonaventura R, Schröder HC, Müller WEG (2005) Monitoring chemical and physical stress using sea urchin immune cells. Prog Mol Subcell Biol 39:85-110

Moore AR (2017) Preparation of cytology samples: tricks of the trade. Vet Clin N Am Small Anim Pract 47:1-16

Ning X, Luo T, Chen Z, Sun Q (2015) The physics for the formation of cell-in-cell structures. Curr Mol Med 15: 867-872

* Ogden JC, Lobel PS (1978) The role of herbivorous fishes and urchins in coral reef communities. Environ Biol Fishes 3:49-63

Ogden NB, Ogden JC, Abbott IA (1989) Distribution, abundance and food of sea urchins on a leeward Hawaiian reef. Bull Mar Sci 45:539-549

Overholtzer M, Mailleux AA, Mouneimne G, Normand G and others (2007) A nonapoptotic cell death process, entosis, that occurs by cell-in-cell invasion. Cell 131:966-979

* Perpiñan D, Hernandez-Divers SM, McBride M, Hernandez-Divers SJ (2006) Comparison of three different techniques to produce blood smears from green iguanas, Iguana iguana. J Herpetol Med Surg 16:99-101

* Pinsino A, Matranga V (2015) Sea urchin immune cells as sentinels of environmental stress. Dev Comp Immunol 49:198-205

* Pinsino A, Della Torre C, Sammarini V, Bonaventura R, Amato E, Matranga V (2008) Sea urchin coelomocytes as a novel cellular biosensor of environmental stress: a field study in the Tremiti Island Marine Protected Area, Southern Adriatic Sea, Italy. Cell Biol Toxicol 24:541-552

Queiroz V, Custodio MR (2015) Characterisation of the spherulocyte subpopulations in Eucidaris tribuloides (Cidaroida: Echinoidea). Ital J Zool 82:338-348 
R Development Core Team (2011) R: a language and environment for statistical computing. R Foundation for Statistical Computing, Vienna

Rahman MA, Uehara T, Pearse JS (2001) Hybrids of two closely related tropical sea urchins (genus Echinometra): evidence against postzygotic isolating mechanisms. Biol Bull (Woods Hole) 200:97-106

Rice WR (1989) Analyzing tables of statistical tests. Evolution 43:223-225

Romanowsky D (1891) Zur Frage der Parasitologie und Therapie der Malaria. St Petersbg Med Wochenschr 16: 297-315

Schalm OW (1962) Practical veterinary hematology. Can Vet J 3:116-119

Shapiro SS, Wilk MB (1965) An analysis of variance test for normality (complete samples). Biometrika 52:591-611

Silva JRMC (2013) Immunology in sea urchins. In: Lawrence JM (ed) Sea urchins: biology and ecology. Elsevier, Amsterdam, p 187-194

Smith LC, Rast JP, Brockton V, Terwilliger DP, Nair SV, Buckley KM, Majeske AJ (2006) The sea urchin immune system. Invertebr Surviv J 3:25-39

Smith LC, Arizza V, Barela Hudgell MA, Barone G and others (2018) Echinodermata: the complex immune system in echinoderms. In: Cooper EL (ed) Advances in compar- ative immunology. Springer International Publishing, Cham, p 409-501

Stimson J, Larned ST, Conklin E (2001) Effects of herbivory, nutrient levels, and introduced algae on the distribution and abundance of the invasive macroalga Dictyosphaeria cavernosa in Kaneohe Bay, Hawaii. Coral Reefs 19: 343-357

Stimson J, Cunha T, Philippoff J (2007) Food preferences and related behavior of the browsing sea urchin Tripneustes gratilla (Linnaeus) and its potential for use as a biological control agent. Mar Biol 151:1761-1772

*Vethamany V, Fung M (1972) The fine structure of coelomocytes of the sea urchin Strongylocentrotus dröbachiensis (Müller O.F.). Can J Zool 50:77-81

Westbrook CE, Ringang RR, Cantero SMA, HDAR \& TNC Urchin Team, Toonen RJ (2015) Survivorship and feeding preferences among size classes of outplanted sea urchins, Tripneustes gratilla, and possible use as biocontrol for invasive alien algae. PeerJ 3:e1235

* Work TM, Dagenais J, Weatherby TM, Balazs GH, Ackermann M (2017) In vitro replication of Chelonid herpesvirus 5 in organotypic skin cultures from Hawaiian green turtles (Chelonia mydas). J Virol 91:e00404-17

Xia P, Wang S, Guo Z, Yao X (2008) Emperipolesis, entosis and beyond: dance with fate. Cell Res 18:705-707

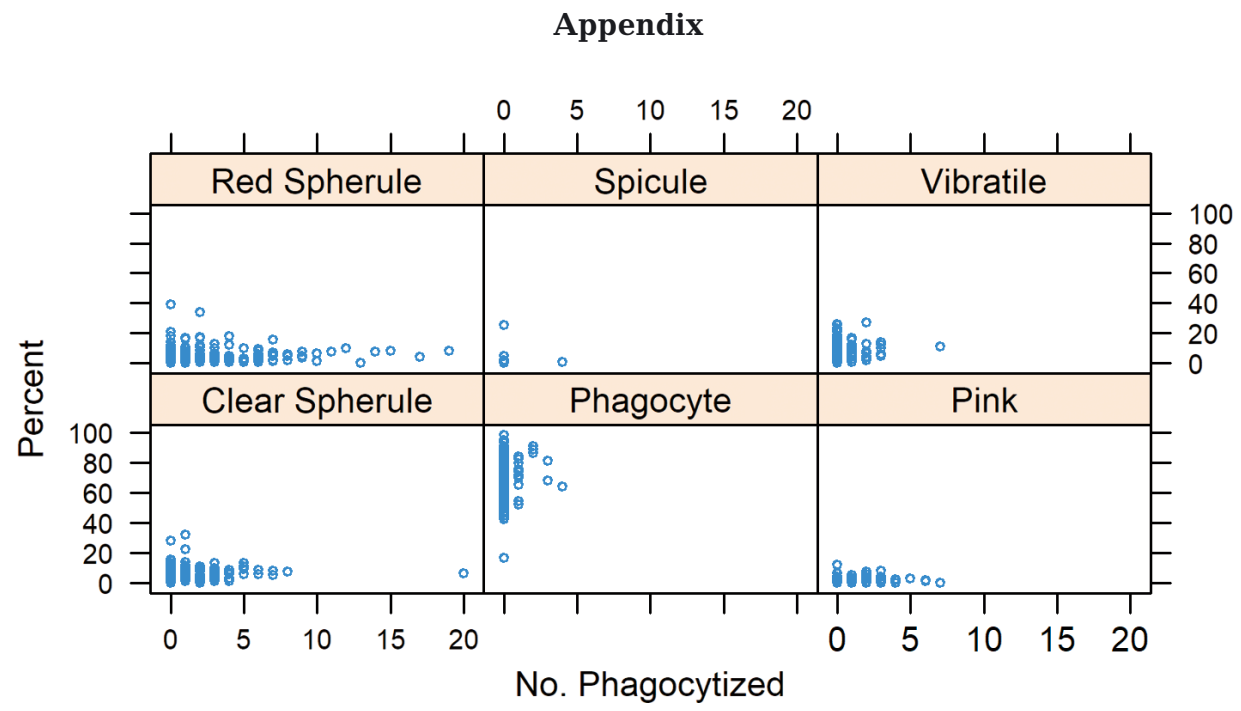

Fig. A1. Plot of percent cell morphotypes vs number of that cell apparently phagocytized by phagocytes for 340 Tripneustes gratilla sampled between January and December 2016. Pink refers to red spherule cells with pink granules; spicule refers to apparently phagocytized spicules

Editorial responsibility: Jeffrey Shields, Gloucester Point, Virginia, USA
Submitted: May 8, 2020; Accepted: September 7, 2020

Proofs received from author(s): November 13, 2020 